No. 21/E/KPT/2018, Tanggal 9 Juli 2018

\title{
Perubahan Histopatologi Ginjal Tikus Putih Diberikan Ekstrak Sarang Semut Diinduksi Parasetamol Dosis Toksik
}

\author{
(HISTOPATHOLOGICAL CHANGES IN WHITE RAT'S KIDNEY GIVEN ANT NEST \\ EXTRACT INDUCED PARACETAMOL TOXIC DOSE)
}

\author{
I Wayan Sudira ${ }^{1 *}$, I Made Merdana ${ }^{1}$, Ida Bagus Oka Winaya ${ }^{2}$, I Kadek Parnayasa ${ }^{3}$ \\ ${ }^{1}$ Laboratorium Farmakologi dan Farmasi Fakultas Kedokteran Hewan, Universitas Udayana, \\ J1. PB. Sudirman Denpasar Bali, Indonesia 80225; \\ ${ }^{2}$ Laboratorium Patologi Fakultas Kedokteran Hewan, Universitas udayana, J1. PB. Sudirman \\ Denpasar Bali, Indonesia 80225; \\ ${ }^{3}$ Praktisi Dokter Hewan Desa Klumpu, Kecamatan Nusapenida, Kabupaten Klungkung Bali, \\ Indonesia 80771. \\ *Email: wayansudira@unud.ac.id
}

\begin{abstract}
ABSTRAK
Penelitian ini bertujuan untuk membuktikan bahwa pemberian parasetamol dosis toksik mempengaruhi histopatologi ginjal dan mengetahui efek sarang semut terhadap efek protektif terhadap ginjal tikus putih yang diberikan parasetamol dosis toksik. Penelitian ini menggunakan 24 ekor tikus putih jantan yang terdiri dari empat perlakuan, yaitu kelompok kontrol P0 tanpa perlakuan, kelompok perlakuan P1 diberi parasetamol dosis $250 \mathrm{mg} / \mathrm{kgBB}$, kelompok perlakuan P2 diberi parasetamol dosis $250 \mathrm{mg} / \mathrm{kgBB}$ ditambah sarang semut dosis $250 \mathrm{mg} / \mathrm{kgBB}$, perlakuan P3 diberikan sarang semut 250 $\mathrm{mg} / \mathrm{kgBB}$ selama tujuh hari setelah itu diberikan ekstrak sarang semut dan parasetamol dosis 250 $\mathrm{mg} / \mathrm{kgBB}$. Parasetamol dan ekstrak sarang semut diberikan secara oral selama sepuluh hari. Setelah itu dilakukan nekropsi dan organ ginjal diambil secara aseptik untuk pembuatan preparat histopatologi dengan pewarnaan Hematoksilin dan Eosin. Variabel yang diperiksa adalah kongesti, pendarahan, nekrosis dan radang. Dari hasil pemeriksaan didapat hasil kerusakan ginjal berupa kengesti, pendarahan, nekrosis dan radang. Uji Kruskall-Wallis menunjukkan adanya perbedaan yang bermakna pada rerata kongesti, pendarahan, nekrosis, dan radang dari kelompok yang diuji. Dari penelitian ini dapat disimpulkan bahwa parasetamol dosis $250 \mathrm{mg} / \mathrm{kgBB}$ dapat menyebabkan kerusakan ginjal. Sarang semut dosis $250 \mathrm{mg} / \mathrm{kgBB}$ mampu memperbaiki kerusakan jaringan ginjal.
\end{abstract}

Kata kunci: ginjal; parasetamol; sarang semut

\begin{abstract}
ABTSRACT
The aims of this study were to prove that the administration of toxic doses of paracetamol affects the histopathology of the kidneys and to know the effect of ant nests on the protective effect on kidney rats given paracetamol toxic dose. This study used 24 male white rats consisting of four treatments, ie control group P0 without treatment, treatment group P1 given paracetamol dose $250 \mathrm{mg} / \mathrm{kg} \mathrm{BW}$, treatment group P2 given paracetamol dose $250 \mathrm{mg} / \mathrm{kgBW}$ plus ant nest dose $250 \mathrm{mg} / \mathrm{kgBW}$, treatment P3 given ant nest $250 \mathrm{mg} / \mathrm{kgBW}$ for seven days after it was given extract of ants and paracetamol dose $250 \mathrm{mg} / \mathrm{kgBW}$. Paracetamol and ant nest extract are administered orally for ten days. After that, necropsies and kidney organs were taken aseptically for the preparation of histopathological preparations with hematoxylin and Eosin staining. The variables examined were congestion, bleeding, necrosis and inflammation. From the examination results obtained results of kidney damage in the form of congesti, bleeding, necrosis and inflammation. The Kruskall-Wallis test showed a significant difference in mean congestion, bleeding, necrosis, and inflammation of the tested group. From this study it can be concluded that paracetamol dose $250 \mathrm{mg} / \mathrm{kg}$ BW can cause kidney damage. Ant nest dose $250 \mathrm{mg} / \mathrm{kg}$ BW able to repair damage to kidney tissue.
\end{abstract}

Keywords: kidney; paracetamol; ant nests 


\section{PENDAHULUAN}

Indonesia adalah mega biodivercity country untuk flora dan fauna. Banyak diantaranya yang memiliki senyawa aktif dan berguna sebagai obat. Obat tradisional dan tanaman obat banyak digunakan masyarakat terutama dalam upaya preventif, promotif, dan rehabilitatif (Bustanussalam, 2010). Obat tradisional yang salah satunya diperkenalkan pada tahun 2006, yang berasal dari pedalaman Papua adalah sarang semut (Alam dan Waluyo, 2006); Subroto dan Saputro, 2006).

Sarang semut (Myrmecodia pendans) merupakan tumbuhan epifit yang menempel di pohon-pohon besar (Alam dan Waluyo, 2006). Sarang semut mengandung senyawa-senyawa kimia dari golongan flavonoid dan tanin yang diketahui mampu menyembuhkan berbagai macam penyakit (Soeksmanto et al., 2010). Secara empiris, rebusan sarang semut dapat menyembuhkan beragam penyakit ringan dan berat seperti kanker, asam urat, jantung koroner, wasir, tuberkulosis, migren, rematik, dan leukimia (Soeksmanto et al., 2009). Sarang semut mampu meningkatkan fungsi fisiologis tubuh terhadap serangan penyakit dan radikal bebas, salah satu metabolit reaktif yang sering timbul akibat penggunaan dosis tinggi seperti penggunaan parasetamol (Sudiono et al., 2015).

Parasetamol merupakan obat analgetik non narkotik dengan cara kerja menghambat sintesis prostaglandin. Parasetamol digunakan secara luas di berbagai negara baik dalam bentuk sediaan tunggal sebagai analgetik antipiretik maupun kombinasi dengan obat lain dalam sediaan obat flu, melalui resep dokter atau yang dijual bebas. Beberapa peneliti lain menyatakan pada dosis yang tinggi, parasetamol dapat menimbulkan iritasi, erosi, ulkus, perdarahan lambung dan kerusakan ginjal mirip seperti efek gastrointestinal obat-obat non steroid anti inflamasi drugs (NSAIDs) (Atmaja, 2008). Menurut Wilson (2005), Adinata et al.
(2012) dan Suparman (2013), ginjal merupakan salah satu organ tubuh yang vital, karena berfungsi mengekskresikan sisa-sisa metabolisme tubuh. Melihat potensi sarang semut sebagai obat promotif dan rehabilitatif serta efek samping parasetamol terhadap ginjal tikius putih maka perlu dilakukan penelitian untuk mengetahui pengaruh ekstrak sarang semut terhadap efek samping parasetamol pada organ ginjal tikus putih.

\section{METODE PENELITIAN}

\section{Materi penelitian}

Penelitian ini menggunakan 24 ekor tikus putih jantan galur wistar, berumur 2-3 bulan, berat badan 200-300 g yang diperoleh di Kota Denpasar, Provinsi Bali.. Spesimen yang digunakan adalah organ ginjal dari hewan coba yang telah diberikan perlakuan. Alat yang digunakan dalam penelitian ini antara lain kandang tikus yang berupa bak plastik bertutup kawat dan diberi alas sekam padi serta dilengkapi dengan tempat makan dan air minum, sonde lambung, spuit $1 \mathrm{ml}$, timbangan digital, mikroskop binokuler, gelas objek, kaca penutup, alat bedah, tissue cassette, staining jar, embedding set, dan microtome. Bahan yang digunakan dalam penelitian ini antara lain tikus putih (Rattus novergius) galur wistar, sarang semut sudah disediakan dalam bentruk ekstrak ethanol, parasetamol, pakan (pellet), air minum, larutan Neutral Buffer Formalin (NBF) $10 \%$. Bahan yang digunakan untuk pembuatan preparat histopatologi dengan pewarnaan HE (Haematoxilin-Eosin), alkohol 70\%, alkohol 80\%, alkohol 90\%, alkohol 96\%, alkohol absolut,toluena, dan paraffin.

\section{Metode penelitian}

Penelitian ini menggunakan ekstrak sarang semut dengan dosis $250 \mathrm{mg} / \mathrm{kg} \mathrm{BB}$, sedangkan untuk dosis paracetamol menggunakan dosis $250 \mathrm{mg} / \mathrm{kg}$ BB. Percobaan menggunakan 24 ekor tikus putih jantan yang dibagi menjadi empat kelompok sebagai berikut: 
P0: Diberikan pakan dan minum

P1: Diberikan parasetamol dengan dosis $250 \mathrm{mg} / \mathrm{kgBB}$ selama 10 hari.

P2: Diberikan ekstrak sarang semut dengan dosis $250 \mathrm{mg} / \mathrm{kgBB}$ + parasetamol dengan dosis $250 \mathrm{mg} / \mathrm{kgBB}$ selama 10 hari.

P3: Diberikan ekstrak sarang semut dengan dosis $250 \mathrm{mg} / \mathrm{kgBB}$ selama 7 hari, setelah itu diberikan ekstrak sarang semut dengan dosis $250 \mathrm{mg} / \mathrm{kgBB}$ + parasetamol dengan dosis $250 \mathrm{mg} / \mathrm{kgBB}$. selama 10 hari.

Sampel dengan empat kelompok perlakuan yang masing-masing terdiri dari enam kali ulangan. Spesimen yang diambil adalah organ ginjal dan dilanjutkan pembuatan preparat histopatologi dengan pewarnaan menggunakan metode Hematoxylyin-Eosin. Preparat histopatologi diamati di bawah mikroskop dengan perbesaran 400x dilihat dengan lima lapang pandang berbeda dan dicatat perubahan mikroskopis berdasarkan parameter yang diamati. Preparat histopatologis diamati dan diskoring berdasarkan kategori berikut:

Skor 0: tidak ada perubahan

Skor 1: bersifat fokal (ringan)

Skor 2: bersifat multifokal (sedang)

Skor 3: bersifat difusa (parah)

Analisis Data

Untuk mengetahui perbedaan struktur histopatologi hepar tikus putih pada masing-masing dosis yang diberikan, data ditabulasi dan selanjutnya dianalisis dengan uji statistik non parametrik Kruskal-Wallis. jika ada perbedaan nyata $(\mathrm{P}<0,05)$ dilanjutkan dengan uji Mann-Whitney.

\section{HASIL DAN PEMBAHASAN}

Hasil pengamatan histopatologi ginjal tikus putih yang diberikan ekstrak sarang semut dan diinduksi parasetamol dosis toksik adalah sebagai berikut: perubahan kongesti fokal ditemukan pada satu jaringan ginjal pada perlakuan kontrol (P0), lima jaringan ginjal pada perlakuan $\mathrm{P} 1$, tiga jaringan ginjal pada perlakuan P2. Sedangkan pada perlakuan P3 tidak ditemukan perubahan kongesti.

Perubahan pendarahan bersifat fokal ditemukan empat jaringan ginjal pada perlakuan kontrol (P0) dan P1, tiga jaringan ginjal pada perlakuan P2 dan satu jaringan ginjal pendarahannya bersifat multifokal. Sedangkan pada perlakuan P3 perdarahan fokal hanya ditemukan pada satu jaringan ginjal.

Perubahan nekrosis bersifat fokal ditemukan tiga jaringan ginjal pada perlakuan kontrol (P0), dua jaringan ginjal pada perlakuan $\mathrm{P} 1$, dan empat jaringan ginjal pada perlakuan P1 nekrosisnya bersifat multifokal. Empat jaringa ginjal pada perlakuan P2 menunjukan adanya nekrosis fokal, dan satu jaringan ginjal menunjukkan adanga perubahan nekrosis yang bersifat multifokal. Sedangkan pada perlakuan P3 lima jaringan ginjal menunjukkan adanya perubahan nekrosis yang bersifat fokal, dan nekrosis multifokal hanya ditemukan pada satu jaringan ginjal.

Perubahan peradangan yang bersifat fokal ditemukan pada tiga jaringan ginjal pada perlakuan kontrol (P0), empat jaringan ginjal pada perlakuaan $\mathrm{P} 1$ dan $\mathrm{P} 2$, dan satu peradangan bersifat multifokal ditemuakan pada perlakuan P2. Sedangkan pada perlakuan P3 hanya ditemukan satu jaringan ginjal yang mengalami radang yang bersifat fokal. Hasil pemeriksaan histopatologi jaringan ginjal yang diberikan ekstrak sarang sarang semut yang diinduksi parasetamol dosis toksik dapat dilihat pada Gambar 1 di bawah ini. Sementara rata-rata hasil skoring kongesti, pendarahan, nekrosis dan radang pada ginjal tikus putih masing-masing perlakuan dapat dilihat pada Gambar 2. 


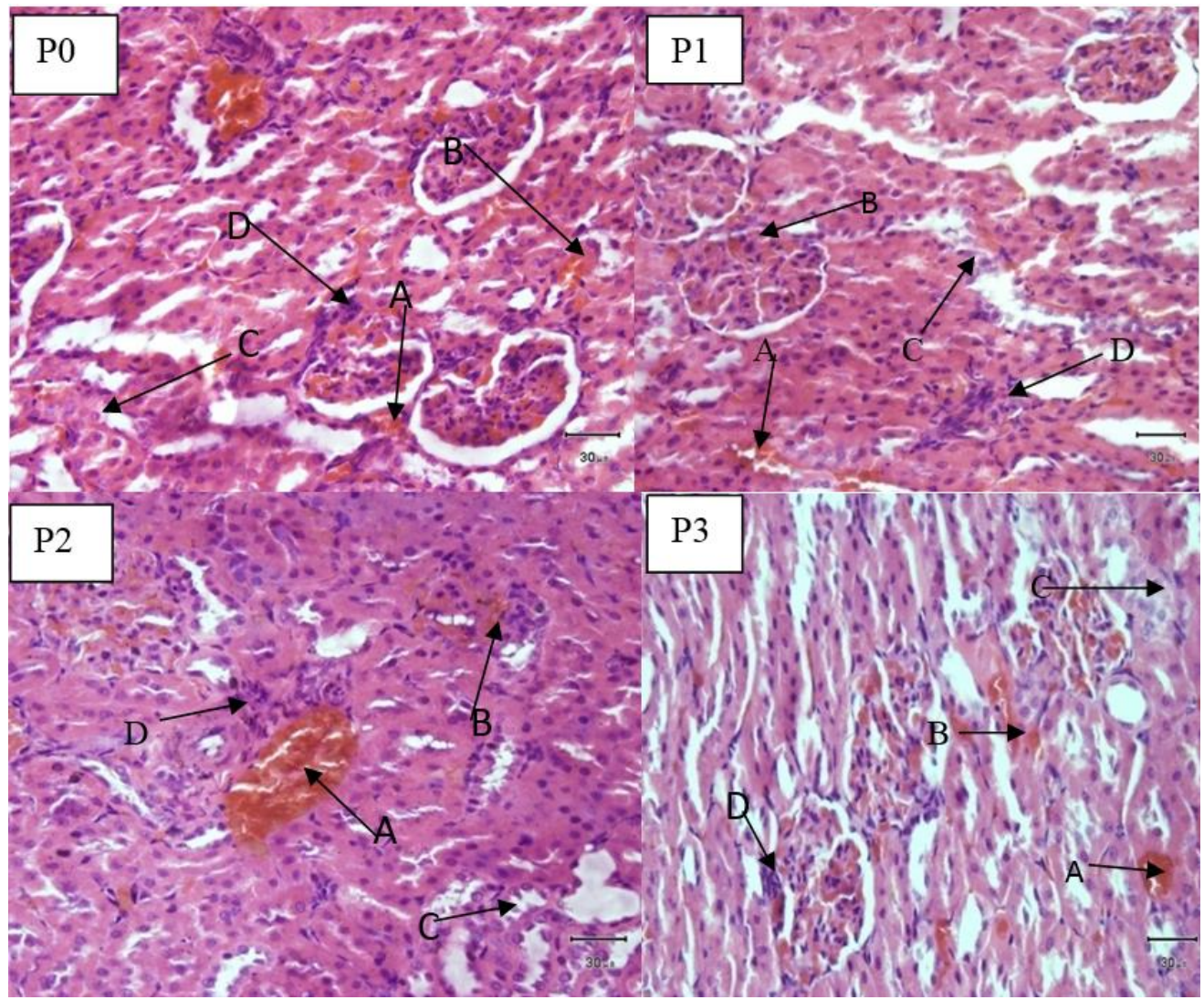

Gambar 1. Gambaran histopatoplogi ginjal tikus putih (Rattus novergicus) pada kelompok P0, P1, P2 dan P3, (HE, 400X). Terlihat adanya kongesti (A), pendarahan (B), nekrosis (C), dan radang (D).

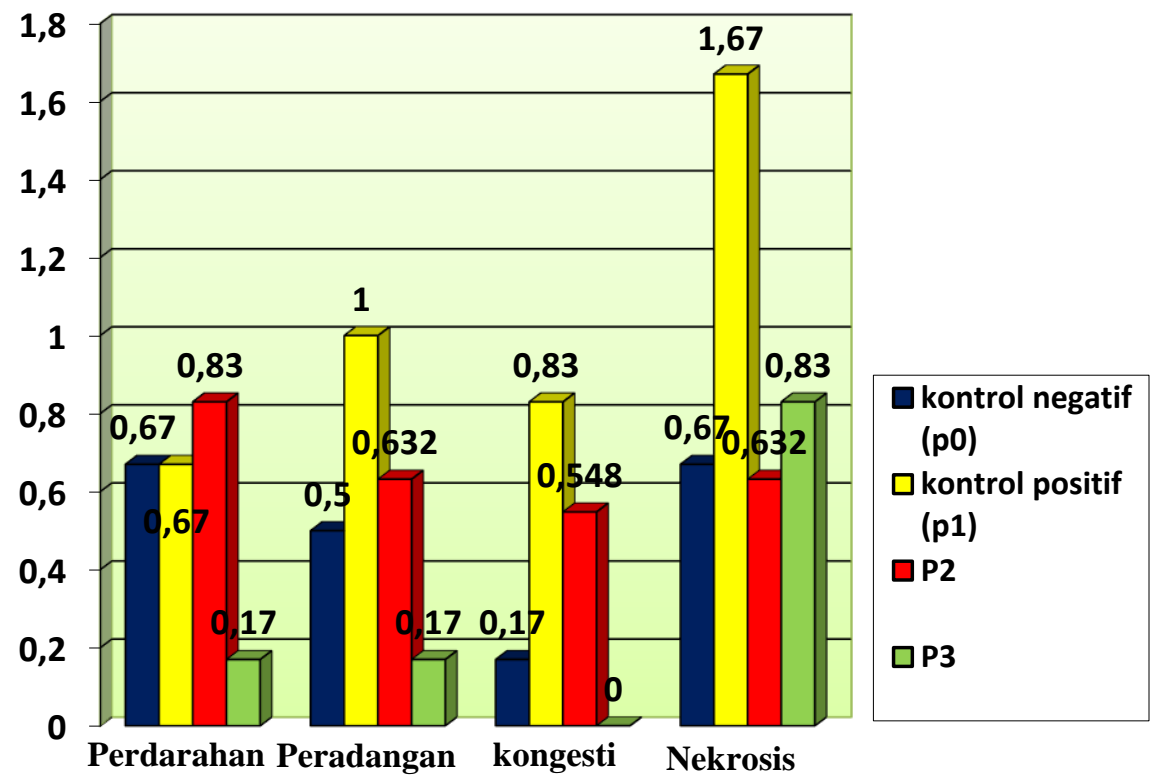

Gambar 2. Grafik rerata skor histopatologi ginjal tikus putih yang diberi parasetamol.

Hasil penelitian ini menunjukkan bahwa pemberian parasetamol dosis toksik mempengaruhi perubahan histopatologi ginjal tikus putih (Rattus norvegicus) dilihat dari lesi kongesti, pendarahan, nekrosis dan radang. Pada perlakuan kontrol negatif (P0) terlihat adanya perubahan kongesti, pendarahan, nekrosis dan radang yang bersifat fokal/ringan. Adanya perubahan histopatologi pada kontrol negatif (P0) dapat diakibatkan oleh status kesehatan tikus percobaan sebelum 
diberi perlakuan. Penggunaan hewan coba konvensional yang tidak bersifat spesific pathogen free (SPF) sering terjadi kontrol negatif mengalami perubahan histopatologi yang tidak diharapkan akibat faktor diluar perlakuan.

Pemberian parasetamol dengan dosis $250 \mathrm{mg} / \mathrm{kg}$ setiap hari mengakibatkan kerusakan pada ginjal. Perubahan yang terjadi adalah kongesti. Kongesti merupakan lesi yang menggambarkan gangguan sirkulasi dan dapat pula sebagai indikator perbaikan jaringan (Kumar et al., 2013).

Perubahan berikutnya adalah pendarahan (Hemoragi) adalah keluarnya darah dari pembuluh darah yang secra patologis di tandai adanya sel darah merah diluar pembuluh darah atau dalam jaringan (Himawan, 1996). Pendarahan dapat dibagi menjadi tiga jenis yaitu petekie, ekimosae dan paint-brush. Petekie adalah pendarahan yang berukuran 1-2 mm. Ekimosae adalah pendarahan dengan ukuran 2-3 cm. Dan paint-brush adalah pendarahan yang bersifat garis-garis. Pada penlitian ini dipadatkan hasil terjadinya pendarahan ringan, begitupula pada kontrol positif dan P2 dan P3.

Perubahan lain yang ditemukan pada pemeriksaan histopatologi ginjal tikus putih yaitu adanya nekrosis. Nekrosis merupakan sel-sel yang mengalami perubahan yang mengarah ke kematian sel, yang disebabkan oleh adanya zat toksik yang masuk bersama dengan aliran darah menuju ke ginjal (Angelina et al., 2000). Nekrosis atau kerusakan sel menurut Ueda dan Shah (2000) yang dikutip dari Kerr et al. (1972), dapat ditandai dengan pembengkakan sel dengan hilangnya membran plasma, perubahan pada organel, dan perubahan inti disertai dengan hipokromik. Penyebab nekrosis salah satunya adalah adanya zat kimia yang bersifat toksin. Pada penelitian ini diperoleh hasil nekrosis yang cenderung sedang.

Perubahan terakhir yang terlihat yaitu adanya peradangan. Peradangan merupakan mekanisme penting yang diperlukan tubuh untuk mempertahankan diri dari berbagai bahaya yang mengganggu keseimbangan juga memperbaiki struktur serta gangguan fungsi jaringan yang ditimbulkan bahaya tersebut (Baratawijaya, 2002). Peradangan yang terjadi pada kontrol negatif, positif, P2, dan P3 bersifat ringan.

Terjadinya perubahan histopatologi pada jaringan ginjal tikus putih setelah pemberian parasetamol $(250 \mathrm{mg} / \mathrm{kgBB})$ ini sesuai dengan teori bahwa proses ekskresi obat yang berlangsung di ginjal dapat menimbulkan dampak buruk bagi ginjal itu sendiri (Robins dan Kumar, 1995). Tingginya aliran darah yang menuju ginjal inilah yang menyebabkan berbagai macam obat dan bahan-bahan kimia dalam sirkulasi sistemik dikirim ke ginjal dalam jumlah yang besar. Zat-zat toksik ini akan terakumulasi di ginjal dan menyebabkan kerusakan bagi ginjal tersebut (Robins dan Kumar, 1995).

Sarang semut memiliki kandungan antioksidan yang berguna untuk meredam efek buruk dari radikal bebas yang dihasilkan oleh parasetamol. Antioksidan adalah zat yang mampu mematikan zat yang lain yang membuat sel menjadi rapuh dan mampu memperbaiki sel yang rusak. Antioksidan merupakan senyawa penting yang berfungsi sebagai penangkal radikal bebas (Atika et al., 2015). Kompenen utama dari sarang semut adalah flavonoid. Flavonoid merupakan antioksidan dan antibiotik yang berfungsi menguatkan dan mengantisipasi kerusakan pembuluh darah dan merupakan bahan aktif yang berfungsi sebagai anti radang dan antivirus (Lilik et al., 2008). Flavonoid yang bekerja untuk memaksimalkan aktivitas scavenger terhadap radikal bebas, dengan cara menurunkan aktivitas radikal hidroksil sehingga tidak terlalu reaktif lagi (Cadenas dan Packer, 2002). Kandungan flavonoid di dalam sarang semut dapat meredam efek buruk radikal bebas, dengan menghambat peroksidasi lipid melalui aktivasi peroksidase terhadap hemoglobin, yang 
merupakan antioksidan endogen (Mot et al., 2009)

Pada penelitian ini didapatkan hasil pemberian ekstrak sarang semut per oral terhadap tikus putih yang sudah diberi parasetamol (250mg/kbBB) mengalami perbaikan pada lesi kongesti dan nekrosis, begitu pula pada lesi perdarahan dan peradangan meskipun secara statistik tidak signifikan $(\mathrm{P}>0,05)$. Khususnya pada $\mathrm{P} 3$ yang diberikan ekstrak sarang semut terlebih dahulu selama tujuh hari dan kemudian diberikan parasetamol dan ekstrak sarang semut, dilihat dari rerata kerusakan hampir mendekati kontrol negatif. Pada P2 juga sudah mampu memperbaiki gambaran histopatologi ginjal tikus putih yang diberikan parasetamol. Sehingga dapat dikatakan bahwa ekstrak sarang semut mampu memperbaiki gambaran histopatologi ginjal tikus putih yang diberikan parasetamol dosis toksik.

\section{SIMPULAN}

Pemberian parasetamol dosis toksik secara peroral dapat menyebabkan perubahan gambaran histopatologi ginjal tikus putih. Pemberian ekstrak sarang semut dosis $250 \mathrm{mg} / \mathrm{kg}$ BB dapat memperbaiki efek toksik dari pemberian parasetamol dosis toksik.

\section{SARAN}

Dengan adanya perbaikan dalam pemberian sarang semut pada ginjal tikus putih yang diberikan parasetamol dosis toksik, maka dapat disarankan untuk memberikan ekstrak sarang semut pada pasien yang menggunakan parasetamol.

\section{UCAPAN TERIMAKASIH}

Penulis mengucapkan terimakasih terutama kepada Balai Besar Veteriner, Denpasar, Propinsi Bali, serta semua pihak yang telah membantu membantu dalam penyelesaian penelitian ini.

\section{DAFTAR PUSTAKA}

Adinata MO, Sudira IW, Berata IK. 2012. Efek ekstrak daun ashitaba (Angelica keiskei) terhadap gambaran histopatologi ginjal mencit (Mus musculus) jantan. Bul. Vet. Udayana. 4(2): 55-62.

Alam S, Waluyo S. 2006. Sarang semut primadona baru dari papua. Majalah Nirmala. Jakarta: PT Gramedia. Pustaka Utama.

Angelina GH, Azmizah A, Soehartojo S. 2000. Pengaruh pemberian air sungai dan PDAM Jangir terhadap perubahan histologis ginjal tikus putih (Rattus novergicus). Media Ked. Hewan. 16(3):180-185.

Atika RH, Muhamad NS, Abdul H, Hamdani B, Zainuddin, Sugito. 2015. Pengaruh pemberian kacang panjang (Vigna unguiculata) terhadap strukturmikroskopis ginjal mencit (Mus musculus) yang diinduksi aloksan. $J$. Med. Vet. 9(1): 18-22.

Atmaja D. 2008. Pengaruh ekstrak kunyit (Curcuma domestica) terhadap gambaran mikroskopik mukosa lambung mencit balb/c yang diberi parasetamol. semarang. Karya tulis ilmiah Fakultas Kedokteran Universitas Diponegoro.

Baratawidjaya KG. 2002. Imunologi Dasar. Jakarta: Balai Penerbit Fakultas Kedokteran UI.

Bustanussalam. 2010. Penentuan struktur molekul dari fraksi air tumbuhan sarang semut (Myrmecodia pendans Merr. dan Perry) yang mempunyai aktivitas sitotoksik dan sebagai antioksidan. Tesis. Sekolah Pascasarjana Institut Pertanian Bogor. Bogor.

Cadenas E, Packer L. 2002. Expanded caffeic acid and related antioxidant compound: Biochemical and cellular effects. Hand book of Antioxidants. $2^{\text {nd }}$ Ed. California, Marcel Dekker, Inc. Pp: 279-303.

Himawan S. 1996. Kumpulan kuliah patologi. UI Press. Jakarta. Hirsch AC, Philipp.

Kerr JF, Wyllie AH, Currie AR. 1972. Apoptosis: a basic biological phenomenon with wide-ranging 
implications in tissue kinetics. Br. J. Cancer. 26:239-57.

Kumar V, Abbas A, Aster J. 2013. Robbins basic pathology. $9^{\text {th }}$ Ed. Student consult. Saunders. Pp: 928.

Lilik E, Khothibul UAA, Umi K, Firman J. 2008. Pengaruh pemberian ekstrak propolis terhadap sistem kekebalan seluler pada tikus putih (Rattus norvegicus) strain Wistar. $J . T e k$. Pertanian. 9(1): 1-8.

Mot AC, Damian G, Sarbu C, Silaghi DR. 2009. Redox reactivity in propolis: direct detection of free radicals in basic medium and interaction with hemoglobin. J. Med. Food. 14(6): 26774.

Robbins dan Kumar. 1995. Buku ajar patologi 1. Edisi 4. Jakarta, EGC. Pp: 290-293.

Soeksmanto A, Simanjuntak P, dan Subroto MA. 2010. Uji toksisitas akut ekstrak air sarang semut (Myrmecodia pendans) terhadap histologi organ hati mencit. J. Nat. Indo. 12(2): 152-155.

Subroto MA, Saputro H. 2006. Gempur penyakit dengan sarang semut. Jakarta. Penebar Swadaya.

Sudiono J, Oka CT, Trisfilha P. 2015 The Scientific Base of Myrmecodia pendans as Herbal Remedies. British J. Med. Medic. Res. 8(3): 230-237.

Suparman IP, Sudira IW, Berata IK. 2013. Kajian ekstrak daun kedondong (Spondias dulcis G.Forst) diberikan secara oral pada tikus putih ditinjau dari histopatologi ginjal. Bul. Vet. Udayana. 5(1): 49-56.

Ueda N, Shah SV. 2000. Role of endonucleases in renal tubular epithelial cell injury. NCBI 8(01): 8-13.

Wilson LM. 2005. Gangguan sistem ginjal. Dalam: Anderson P. S, Wilson L. M (Ed). Patofisiologi konsep klinis. 